\title{
Pyrenophora trichostoma (Pleosporaceae, Pleosporales): an overview of the species and first record on Bromopsis inermis from Russia
}

\author{
Goonasekara ID ${ }^{1,2,3,4}$, Bulgakov TS $^{5}$ and Jayawardena RS $^{1,2 *}$
}

\author{
${ }^{1}$ Center of Excellence in Fungal Research, Mae Fah Luang University, Chiang Rai 57100, Thailand \\ ${ }^{2}$ School of Science, Mae Fah Luang University, Chiang Rai 57100, Thailand \\ ${ }^{3}$ Key Laboratory for Plant Biodiversity and Biogeography of East Asia (KLPB), Kunming Institute of Botany, Chinese \\ Academy of Science, Kunming 650201, Yunnan, P.R. China \\ ${ }^{4}$ World Agroforestry Centre (ICRAF), East and Central Asia Regional Office, Kunming 650201, Yunnan, China \\ ${ }^{5}$ Department of Plant Protection, Federal Research Centre the Subtropical Scientific Centre of the Russian Academy of \\ Sciences, 2/28 Yana Fabritsiusa Street, Sochi 354002, Krasnodar region, Russia
}

Goonasekara ID, Bulgakov TS, Jayawardena RS 2020 - Pyrenophora trichostoma (Pleosporaceae, Pleosporales): an overview of the species and first record on Bromopsis inermis from Russia. Plant Pathology \& Quarantine 10(1), 133-143, Doi 10.5943/ppq/10/1/15

\begin{abstract}
Pyrenophora consists of endophytes, pathogens and saprobes that are widely distributed on various cereal crops and grass hosts. Pyrenophora trichostoma was found on Bromopsis inermis in Russia (Rostov region) and it is described as the first record of this species from this host. The fungus, a sexual morph, was isolated using the single spore isolation technique. The morphology is illustrated and a description has been provided. Sequence data of the LSU and ITS gene regions were analysed to confirm the phylogenetic placement of the species. The history of P. trichostoma, its distribution and economic impact as a pathogen that causes leaf spots on cereals and wheat, has been discussed.
\end{abstract}

Key words - grass fungi - pathogen - phylogeny - saprobe - taxonomy

\section{Introduction}

\section{History}

Pyrenophora is a distinct genus in Pleosporales as it lacks pseudoparaphyses in the hamathecium and have asci with large apical rings and visible ocular chambers (Sivanesan 1984, Ariyawansa et al. 2014). The genus was introduced by Rebentisch (1804) based on the type Pyrenophora phaeocomes (Rebent.) Fr. Drechslera has been confirmed as the asexual morph (Zhang \& Berbee 2001, Ariyawansa et al. 2014, Marin-Felix et al. 2019, Hyde et al. 2020). Pyrenophora species are widespread and a few are well-known plant pathogens (Tekauz 1983, Lamari \& Bernier 1989, Kingsland 1991, Gupta \& Loughman 2001, Ariyawansa et al. 2014). Marin-Felix et al. (2019) accepted 27 species in Pyrenophora based on a multi-gene analysis consisting of ITS, LSU, GAPDH and RPB2 sequence data.

Pyrenophora trichostoma was originally described as Sphaeria trichostoma, a species introduced by Fries (1823) in Hypoxylaceae and later synonymized to this name (Fries 1870). However, no holotype is designated in the original description. Wehmeyer (1961) re-introduced Pyrenophora trichostoma as the sexual morph of Helminthosporium species that were reported on 
several grasses such as Bromus, Hordeum, Poa, Secale and Triticum. This name was then widely used to identify the tan spot or yellow leaf spot pathogen on wheat (Wiese 1977, Hosford 1982). Later, the species was synonymized under $P$. tritici-repentis for having similar morphological characters, such as producing ascospores with mucilaginous sheaths (Ciuffetti \& Tuori 1999, Sivanesan 1984). Based on phylogenetic analysis, Kodsueb et al. (2006) considered them as two distinct species, citing differences in the base pairs of $P$. tritici-repentis and $P$. trichostoma sequences. In the recent study by Marin-Felix et al. (2019) P. trichostoma was accepted as a phylogenetically distinct species.

\section{Morphological characters of the sexual/asexual morph}

During a revision of Drechslera, Pyrenophora tritici-repentis was proposed as the sexual morph of the hyphomycete Drechslera tritici-repentis (Died.) Shoem. by Shoemaker (1959, 1962). Subsequent studies have confirmed the link between the sexual and asexual morphs of these genera based on phylogeny (Zhang \& Berbee 2001, Ariyawansa et al. 2014).

The Pyrenophora sexual morph has immersed to semi-immersed ascomata with necks surrounded by brown to reddish brown setae. The hamathecium comprises no pseudoparaphyses, clavate to saccate shaped asci with large apical rings, and muriform, terete ascospores (Ariyawansa et al. 2014, Marin-Felix et al. 2019, Hyde et al. 2020). Pyrenophora trichostoma has $330 \mu \mathrm{m}$ long and $40 \mu \mathrm{m}$ wide, 8-spored asci, with broad-oblong, asymmetric, muriform, yellow, $52 \times 20 \mu \mathrm{m}$ sized ascospores that are 4-6 septate, with constrictions at the mid septum (Fuckel 1870, translated from Latin). There is no asexual morph reported yet.

In pure culture this species usually forms flat or umbonate colonies, greenish, grey to white, or olivaceous black, which later develop an orangish, brownish or pinkish tint. For sporulation, several media have been proposed as suitable: sterilized rice or wheat straw on PDA, PNA, OA and MEA for asexual morphs, and Sach's agar for the sexual morphs (Marin-Felix et al. 2019).

\section{Diversity of the species}

Pyrenophora trichostoma is widely distributed with most occurrences being from Europe and USA (Far \& Rossman 2020). A compilation of all records of the species from various hosts and regions is listed in Table 1.

Table 1 Reports of Pyrenophora trichostoma on various hosts worldwide.

\begin{tabular}{lll}
\hline \multicolumn{1}{c}{ Host } & \multicolumn{1}{c}{ State/Country } & \multicolumn{1}{c}{ References } \\
\hline Agropyron repens & Canada & Conners (1967) \\
A. smithii & USA & Krupinsky (1982) \\
Avena sp. & Italy & Greuter et al. (1991) \\
Bothriochloa ischaemum* & Russia & Hyde et al. (2020) \\
Bromopsis inermis* & Russia & This study \\
Bromus sp. & England & Dennis (1978) \\
Calamagrostis arundinacea & Poland & Chlebicki (1993) \\
Dactylis sp. & Portugal & Unamuno (1941), Checa (2004) \\
& Spain & Checa (2004) \\
Elymus junceus & USA & Krupinsky (1982), Krupinsky \& Berdahl (1984), \\
& & Checa (2004) \\
Festuca nigricans & Portugal & Checa (2004) \\
& Spain & Checa (2004) \\
Hierochloe alpina, & Alaska & Cash (1953) \\
Hordeum vulgare & China & Tai (1979) \\
H. vulgare var. nudum & China & Tai (1979) \\
Juncus balticus var. montanus & USA & Cooke (1955) \\
Luzula sylvatica & Austria & Scheuer (1988) \\
Poa pratensis & Alaska & Cash (1953) \\
Puccinellia borealis & Alaska & Cash (1953) \\
\hline
\end{tabular}


Table 1 Continued.

\begin{tabular}{|c|c|c|}
\hline Host & State/Country & References \\
\hline P. distans & Poland & Chlebicki (1993) \\
\hline \multirow[t]{3}{*}{ Secale cereal } & Portugal & Checa (2004) \\
\hline & Spain & Checa (2004) \\
\hline & USA & $\begin{array}{l}\text { Index of Plant Diseases in the US (1960), Hanlin } \\
\text { (1963) }\end{array}$ \\
\hline \multirow[t]{3}{*}{ Triticum aestivum } & Bolivia & Farr \& Stevenson (1963) \\
\hline & Brazil & Mendes et al. (1998) \\
\hline & USA & $\begin{array}{l}\text { Index of Plant Diseases in the US (1960), } \\
\text { Hanlin (1963) }\end{array}$ \\
\hline
\end{tabular}

*Molecular data available in GenBank

\section{Molecular data}

The LSU and ITS genes are used as DNA barcodes for Pyrenophora for classification at genus level, while ITS, GAPDH and TEF1 are effective in species identification (Marin-Felix et al. 2019). There is no molecular data available in GenBank for the reports mentioning P. trichostoma as a pathogen. Yet, the pathogenicity of Pyrenophora species is widespread and established, and as a result, researchers have looked into developing molecular genetic markers for rapid identification of the species (Moreno et al. 2012).

\section{Economic importance and pathogenicity}

A form of Pyrenophora trichostoma that severely infected wheat of North Dakota was reported by Hosford (1971) in 1968 and 1969. The disease symptoms showed light-brown lesions with yellow halos on leaves, and many ascostromata present on wheat stubble. The pathogenicity of the fungus varied, as well as the resistance of different wheat cultivars towards the pathogen. This depended on how long the leaves were exposed to free moisture (Hosford 1971). The species was also found pathogenic causing leaf spots on Elymus arenarius and Elymus cinereus from North Dakota (Krupinsky \& Berdahl 1984).

Due to these diseases, cereal crops have faced a high reduction in grain yield and quality leading to the decrease in crop productivity (Porta-Puglia et al. 1986, Wiese 1987, Sivanesan 1987).

\section{Materials \& Methods}

\section{Literature survey}

Published articles in journals, books, web-based resources such as reports on host plants or disease management, USDA database (Farr \& Rossman 2020) and research theses were referred for the literature review. Host names given in the original citation were checked according to The Plant List (http://www.theplantlist.org).

\section{Sample collection, observation and study}

Samples were collected in Russia, into paper bags and brought to the laboratory. A Motic SMZ 168 dissecting microscope was used to observe the fungal morphological features as described in Goonasekara et al. (2019). Photographs were obtained through a Canon EOS 600D digital camera fixed to a Nikon Ni compound microscope. Adobe Photoshop CS5 Extended version 12.0 software (Adobe Systems, USA) was used to process the photos. Measurements were taken with The Tarosoft (R) Image Frame Work program v. 0.9.7 software. The fungus was isolated using single spore isolation, in a petri-dish containing 2\% water agar (Chomnunti et al. 2014) and incubated at $16-18^{\circ} \mathrm{C}$, overnight. Germinating spores were transferred aseptically onto fresh potato dextrose agar (PDA), and further incubated at $16-18^{\circ} \mathrm{C}$. Pure colonies were subcultured into new PDA plates. Herbarium material is deposited in the herbarium of Mae Fah Luang University, Chiang Rai, Thailand (MFLU) and living cultures are deposited at in Kunming Culture Collection (KUMCC) and duplicated at Mae Fah Luang University Culture Collection (MFLUCC). The 
Facesoffungi and Index Fungorum numbers were obtained according to Jayasiri et al. (2015) and Index Fungorum (2020).

\section{DNA extraction, PCR amplification and DNA sequencing}

Genomic DNA was extracted from fresh mycelia grown on PDA, following the manufacturer's standard protocol described in the DNA extraction kit (Biospin Fungus Genomic DNA Extraction Kit). Polymerase chain reactions (PCR) were processed using the primer pairs ITS5 and ITS4, to amplify the internal transcribed spacers (ITS) (White et al. 1990) and LROR and LR5 for large subunit rDNA (LSU) (Vilgalys \& Hester 1990). The amplification reaction was completed in a $25 \mu \mathrm{l}$ total volume containing $1 \mu \mathrm{l}$ DNA, $9.5 \mu \mathrm{l}$ Taq polymerase and PCR buffer mix, $12.5 \mu \mathrm{l}$ double distilled water and $1 \mu \mathrm{l}$ of each primer. The PCR thermal cycling program for LSU and ITS gene regions were as follows: an initial denaturing step of $94^{\circ} \mathrm{C}$ for 3 mins, followed by 35 amplification cycles of $94^{\circ} \mathrm{C}$ for $30 \mathrm{~s}$, annealation at $57^{\circ} \mathrm{C}$ for $45 \mathrm{~s}$, elongation at $72^{\circ} \mathrm{C}$ for 60 $\mathrm{s}$ and a final extension step of $72^{\circ} \mathrm{C}$ for $10 \mathrm{~min}$. PCR products were verified by running $1 \%$ agarose gel electrophoresis, stained with 4S Green Stain. Purification and sequencing of PCR products were carried out at Shanghai Sangon Biological Engineering Technology and Services Co., China. Sequences generated in this study are deposited in GenBank.

\section{Phylogenetic analysis}

Sequence results obtained were subjected to BLASTn (NCBI) searches to obtain matching sequences from GenBank (Table 1) and from recent publications (Marin-Felix et al. 2019). An analysis of the combined LSU and ITS sequences of accepted Pyrenophora species were included to confirm the phylogenetic placement of our strain, with Bipolaris panici-miliacei (CBS 199.29) and B. yamadae (CBS 202.29) as the outgroup taxa. Single gene sequences were assembled in BioEdit v. 7.0.9.0 (Hall 1999). Multiple sequence alignments were generated with MAFFT v. 7 (http://mafft.cbrc.jp/alignment/server/index.html) and manually improved using MEGA v.6 for maximum alignment and minimum gaps. Evolutionary models for phylogenetic analyses were independently selected for each gene region following the Akaike Information Criterion (AIC) of the MrModeltest v. 3.7 (Nylander 2004). Phylogenetic reconstructions of combined gene trees were performed using maximum likelihood (ML), maximum parsimony (MP) and Bayesian inference (BI) criteria.

The ML analysis was performed using RAxML-HPC2 on XSEDE (8.2.8) (Stamatakis et al. 2008, Stamatakis 2014) in the CIPRES Science Gateway platform (Miller et al. 2010) with $\mathrm{GTR}+\mathrm{I}+\mathrm{G}$ as the model of evolution and bootstrap support obtained by running 1000 pseudo replicates. The MP analysis was performed using PAUP (Phylogenetic Analysis Using Parsimony) v. 4.0b10 (Swofford 2002). Ambiguously aligned regions were excluded and gaps were treated as missing data. The trees were inferred using the heuristic search option with TBR branch swapping and 1000 random sequence additions. Maxtrees were setup to 1000, branches of zero length were collapsed and all multiple parsimonious trees were saved. Descriptive tree statistics for parsimony tree length [TL], consistency index [CI], retention index [RI], relative consistency index $[\mathrm{RC}]$ and homoplasy index [HI] were calculated. The robustness of the most parsimonious trees was evaluated by 1000 bootstrap replications resulting from maximum parsimony analysis, each with ten replicates of random stepwise addition of taxa (Felsenstein 1985). The Kishino-Hasegawa tests (KHT) (Kishino \& Hasegawa 1989) were performed to determine whether the trees were significantly different. The BI analysis was conducted using MrBayes v. 3.1.2 (Huelsenbeck \& Ronquist 2001) to evaluate posterior probabilities (BYPP) (Rannala \& Yang 1996, Zhaxybayeva \& Gogarten 2002) by Markov chain Monte Carlo sampling (BMCMC). Six simultaneous Markov chains were run for $1,000,000$ generations and trees were sampled every $100^{\text {th }}$ generation. First The burn-in phase of $20 \%$ was set and critical value for the topological convergence diagnostic set to 0.01 .

Phylograms were visualized using FigTree v1.4.0 program (Rambaut 2012) and re-edited and formatted using Microsoft Power Point (2013) and Adobe Photoshop CS6 extended version 13.1.2 
software. The final tree alignment was submitted to TreeBASE (Submission ID: 27122, http://www.treebase.org/).

Table 2 GenBank accession numbers of the strains used for phylogenetic analysis. Sequences generated in this study are in blue. Type strains are in bold.

\begin{tabular}{|c|c|c|c|}
\hline \multirow[t]{2}{*}{ Taxon } & \multirow[t]{2}{*}{ Culture code } & \multicolumn{2}{|c|}{ GenBank accession numbers } \\
\hline & & ITS & LSU \\
\hline Bipolaris panici-miliacei & CBS 199.29LT & MH855043 & MH866507 \\
\hline B. yamadae & CBS 202.29 & MH855044 & MH866508 \\
\hline Pyrenophora avenicola & CBS $307.84^{\mathrm{T}}$ & MK539972 & MK540042 \\
\hline \multirow{2}{*}{ P. biseptata } & CBS 319.69 & MK539974 & MK540044 \\
\hline & CBS 108963 & MK539975 & JN712532 \\
\hline \multirow[t]{2}{*}{ P. bromi } & CBS 311.68 & MK539976 & MH870851 \\
\hline & DAOMC 127414 & JN943666 & JN940074 \\
\hline P. chaetomioides & CBS 195.31 & MK539978 & MH866633 \\
\hline P. cynosuri & CBS 127918 $^{\mathrm{T}}$ & MK539980 & MK540047 \\
\hline P. dactylidis & DAOMC 92161 & JN943667 & JN940087 \\
\hline \multirow[t]{2}{*}{ P. dictyoides } & DAOMC 63666 & JN943653 & JN940080 \\
\hline & CBS 258.80 & MK539981 & MK540048 \\
\hline \multirow[t]{2}{*}{ P. erythrospila } & CBS 312.69 & MK539983 & MK540051 \\
\hline & CBS 108941 & MK539984 & MK540052 \\
\hline P. fugax & CBS 509.77 & MK539985 & MK540053 \\
\hline \multirow[t]{2}{*}{ P. grahamii } & CBS 315.69 & MK539986 & MK540054 \\
\hline & CBS 128043 & MK539987 & MH876230 \\
\hline$P$. japonica & CBS $281.31^{\mathrm{RS}}$ & MK540004 & MK540067 \\
\hline \multirow{3}{*}{ P. leucospermi } & CBS $111083^{T}$ & JN712467 & JN712533 \\
\hline & CBS 111505 & MK539989 & JN712542 \\
\hline & CBS 114493 & MK539990 & JN712545 \\
\hline P. lolii & CBS 240.48 & MK539991 & MK540055 \\
\hline \multirow[t]{2}{*}{ P. nisikadoi } & CBS $190.29^{\mathrm{ET}}$ & KM257054 & KM243296 \\
\hline & CBS 119213 & EU552124 & MK540056 \\
\hline \multirow[t]{2}{*}{ P. nobleae } & CBS 259.80 & MK539994 & MK540058 \\
\hline & CBS 127936 & MK539996 & MK540060 \\
\hline P. novozelandica & CBS $127934^{\mathrm{T}}$ & MK539997 & MK540061 \\
\hline$P$. phaeocomes & DAOMC 222769 & JN943649 & JN940093 \\
\hline \multirow[t]{2}{*}{ P. poae } & CBS $319.68^{\mathrm{RS}}$ & MK539998 & MK540062 \\
\hline & CBS 128045 & MK539999 & MH876232 \\
\hline P. pseudoerythrospila & CBS $127931^{\mathrm{T}}$ & MK540000 & MK540063 \\
\hline P. semeniperda & DAOMC 213153 & JN943665 & JN940088 \\
\hline$P$. sieglingiae & CBS 127930 & MK540002 & MK540065 \\
\hline P. teres f. maculata & CBS 228.76 ${ }^{\mathrm{T}}$ & MK540003 & MK540066 \\
\hline P. teres & CBS 336.29 & MK540007 & MH877692 \\
\hline \multirow{2}{*}{ P. tetrarrhenae } & DAOMC 171966 & JN943663 & JN940090 \\
\hline & CBS 127924 & MK540011 & MH877965 \\
\hline \multirow[t]{5}{*}{ P. trichostoma } & CBS 328.53 & MK540012 & MK540072 \\
\hline & CBS 391.54 & MK540013 & MK540073 \\
\hline & CBS 392.54 & MK540014 & MK540074 \\
\hline & KUMCC 16-0120 & MN736436 & MN733192 \\
\hline & KUMCC 16-0123 & MW041570 & MW041254 \\
\hline$P$. triseptata & CBS 128047 & MK540015 & MH877983 \\
\hline P. tritici-repentis & CBS 259.59 & MK540017 & MK540075 \\
\hline P. tritici-repentis & CBS 191.29 & MK540018 & MK540076 \\
\hline P. tritici-repentis & CBS 127922 & MK540019 & MK540077 \\
\hline$P$. variabilis & CBS $127920^{\mathrm{T}}$ & MK540020 & MK540078 \\
\hline$P$. wirreganensis & CBS 109896 & MK540021 & MK540079 \\
\hline
\end{tabular}

(ET = epitype, $\mathrm{LT}$ = lectotype, RS = reference strain, $\mathrm{T}$ = type $)$ 


\section{Results \& Discussion}

\section{Phylogeny}

A combined dataset of the LSU and ITS sequences of 46 Pyrenophora strains were subjected to the phylogenetic analyses, with Bipolaris panici-miliacei CBS 199.29 and B. yamadae CBS 202.29 as the outgroup taxa (Fig. 1). Bootstrap values equal to or greater than $60 \%$ obtained for MP and ML analyses and BYPP values equal to or greater than 0.90 resulting from the BI analysis are given at each node (Fig. 1).

The MP dataset consisted of 1780 characters, of which 1465 characters were constant, 266 were parsimony-informative and 49 were parsimony-uninformative. The most parsimonious tree with a tree length of 900 , had the following values: $\mathrm{CI}=0.563, \mathrm{RI}=0.777, \mathrm{RC}=0.438, \mathrm{HI}=$ 0.437 and is presented in Fig. 1. The tree topology of the ML and BI analysis did not differ significantly from that of the MP analysis. The RAxML analysis of the combined dataset yielded a best scoring tree with a ML optimization likelihood value of -7078.475836. The matrix had 461 distinct alignment patterns, with $13.71 \%$ of undetermined characters or gaps. Parameters for the GTR model of the combined ITS and LSU were as follows: estimated base frequencies; $\mathrm{A}=$ $0.245334, \mathrm{C}=0.229315, \mathrm{G}=0.279163, \mathrm{~T}=0.246188$; substitution rates $\mathrm{AC}=1.521880, \mathrm{AG}=$ 1.485545, $\mathrm{AT}=1.366202, \mathrm{CG}=0.879594, \mathrm{CT}=3.736353$, $\mathrm{GT}=1.000000$; gamma distribution shape parameter $\alpha=0.104747$. The BI analysis resulted in 40,002 trees after 1,000,000 generations. The first 2000 trees, representing the burn-in phase of the analyses, were discarded, while the remaining 9001 trees were used for calculating posterior probabilities in the majority rule consensus. The average standard deviation of split frequencies was 0.010067 .

Our isolate KUMCC 16-0123 together with other Pyrenophora trichostoma isolates CBS 328.53, CBS 391.54, CBS 392.54 and KUMCC 16-0120 formed a clade with strong bootstrap support (100\% MP/100\% ML/1 BYPP), sister to P. bromi.

\section{Taxonomy}

Pyrenophora trichostoma (Fr.) Fr., Jb. nassau. Ver. Naturk. 23-24: 215 (1870) [1869-70] Fig. 2 Saprobic on dead stems of Bromopsis inermis (Leyss.) Holub Sexual morph: Ascomata 320$420 \mu \mathrm{m}$ high $300-345 \mu \mathrm{m}$ diam. $(\bar{x}=400 \times 320 \mu \mathrm{m}, \mathrm{n}=10)$, black, immersed to semi-immersed or becoming erumpent, solitary or scattered, uniloculate, globose to subglobose, or conical, visible as shiny black dome shaped structures on the host surface, conspicuous, surrounded by setae, glabrous, non-papillate, black. Ostiole short, immersed, round, with a pore-like opening. Setae dark brown, darker towards the base, septate, tapering towards the apex. Peridium 16-26 $\mu \mathrm{m}$ wide, thin, multiple-layered cells of outer dark brown textura angularis, and inner cells of pale brown to hyaline flattened textura angularis to textura prismatica. Hamathecium consisting of irregular shaped cellular matter, pseudoparaphyses absent. Asci 250-350 × 45-65 $\mu \mathrm{m},(\bar{x}=310 \times 50 \mu \mathrm{m}, \mathrm{n}=$ 20), 8-spored, bitunicate, fissitunicate, slightly curved, broadly cylindric-clavate, smooth-walled, with a bi-lobed, short pedicel, apex rounded, with a distinct ocular chamber. Ascospores 35-70 $\times$ 15-35 $\mu \mathrm{m},(\bar{x}=55 \times 20 \mu \mathrm{m}, \mathrm{n}=40)$, overlapping biseriate, ellipsoidal, asymmetrical, muriform, with 3 transverse septa, 1-2 longitudinal septa, constricted at the septa, thick-walled, cells with longitudinal septa larger or swollen, hyaline when immature, pale to golden brown when mature, end cells slightly lighter, conical and broadly to narrowly rounded at the ends, surrounded by a thick mucilaginous sheath, guttulate. Asexual morph: Undetermined.

Culture characteristics - Colonies on PDA reaching approximately $2.5 \mathrm{~cm}$ diam after 7 days at $16-18^{\circ} \mathrm{C}$, pinkish white, circular, flat, with dense mycelium, smooth margins, becoming orangish red and reverse brown.

Material examined - RUSSIA, Rostov region, Shakhty city district, 20th anniversary of Red Army microdistrict, Solyonaya Balka (Salty gully), at margin of artificial forest, on dead stems of Bromopsis inermis (Leyss.) Holub (Poaceae), 21 May 2015, Timur S. Bulgakov, T-431 (MFLU 152135, new host record); living culture KUMCC 16-0123. 


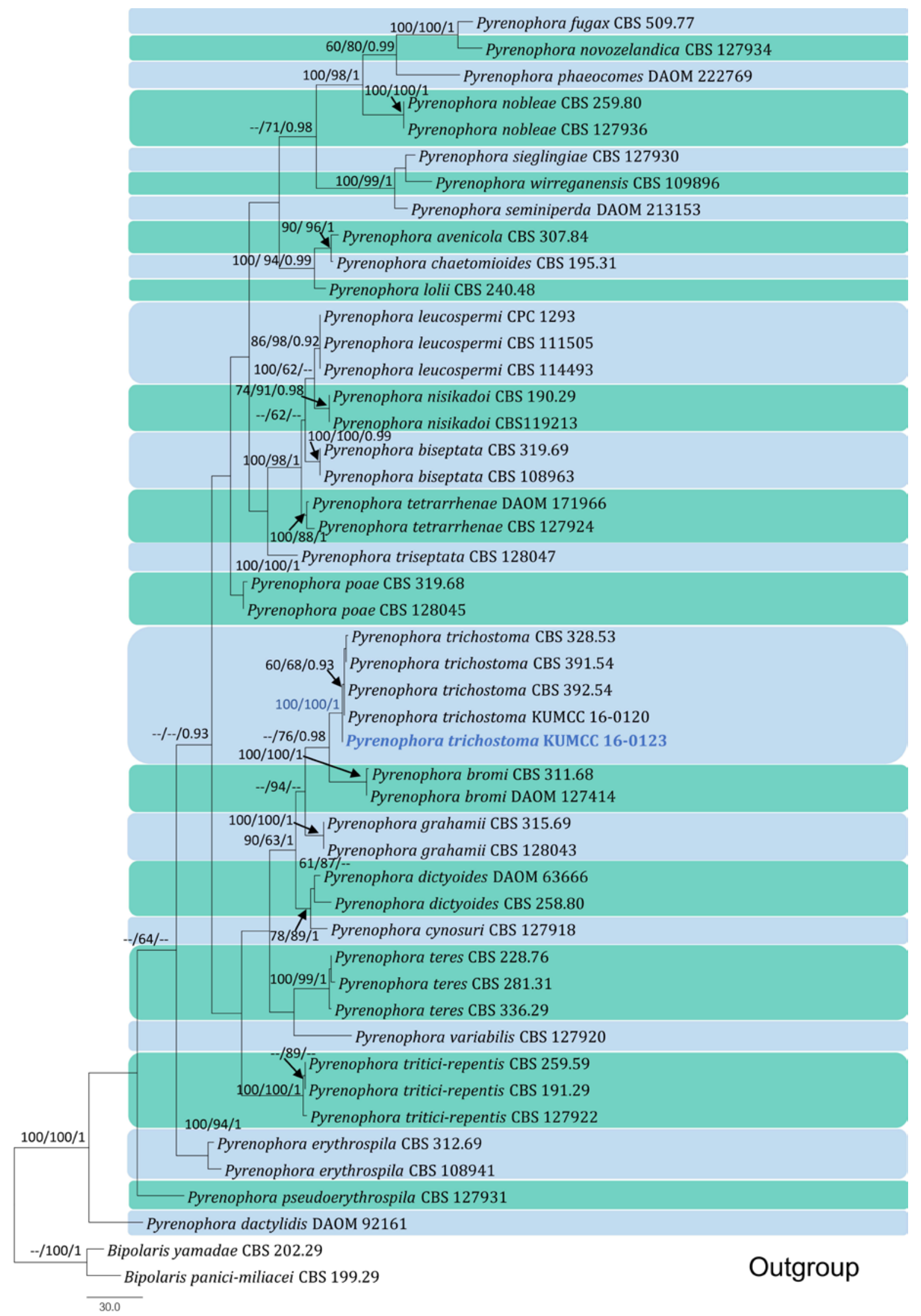

Fig. 1 - Phylogram generated from maximum parsimony (MP) analysis based on combined LSU and ITS sequence data. Bootstrap values for MP and maximum likelihood (ML) analyses equal to or greater than $60 \%$ and Bayesian posterior probabilities (BYPP) greater than 0.9 are given at the nodes, respectively. The tree is rooted to Bipolaris panici-miliacei CBS 199.29 and B. yamadae CBS 202.29. Ex-type strains are in bold. The newly generated isolate is indicated in blue. 

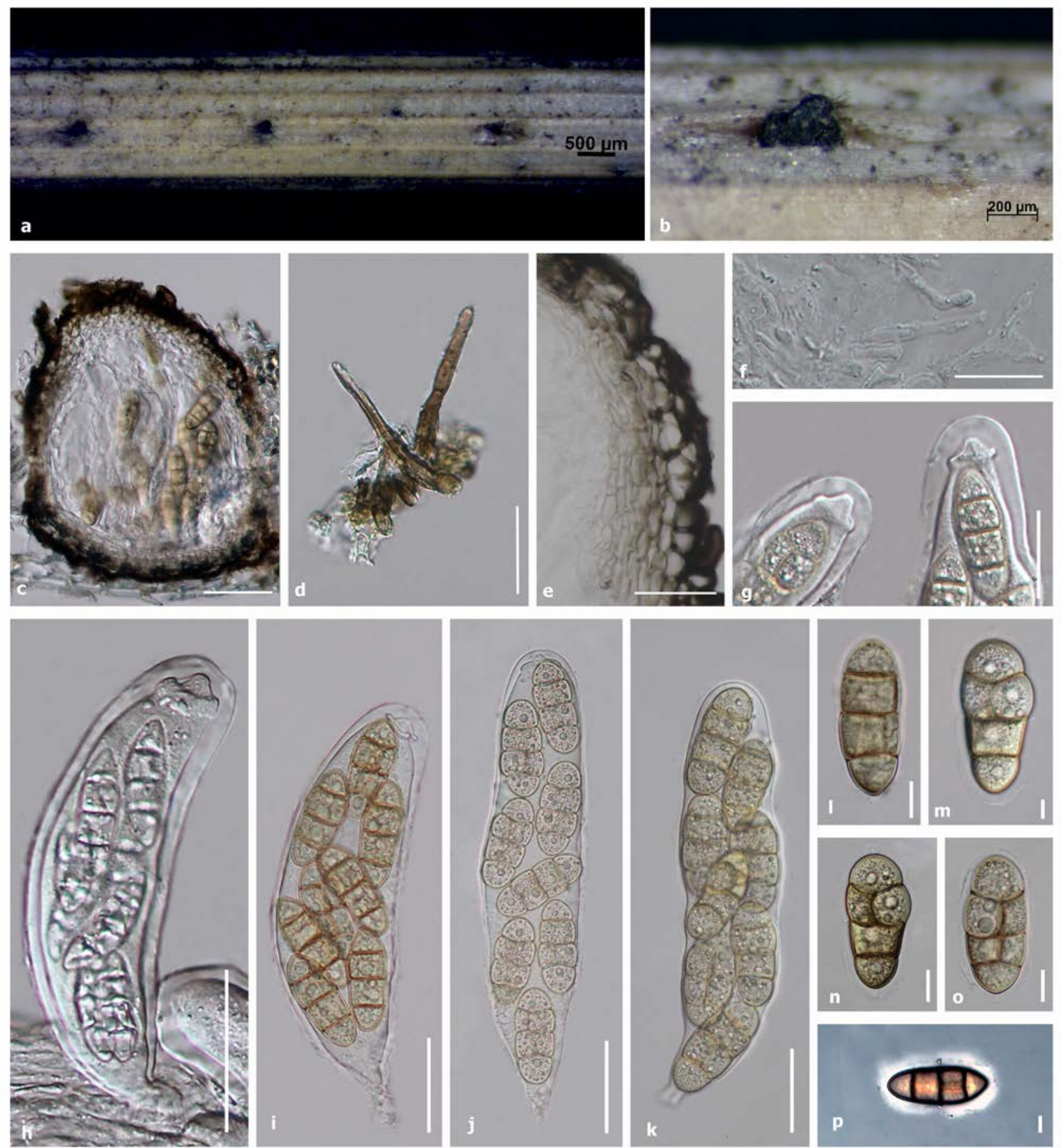

Fig. 2 - Pyrenophora trichostoma (MFLU 15-2135, new host record). a Appearance of ascomata on host. b Close up of ascoma. c Section of ascoma. d Setae. e Peridium. f Contents of the hamathecium. g Ocular chambers of asci. h-k Immature to mature asci. l-o Ascospores. p Ascospore surrounded in a sheath (stained with Indian Ink). - Scale bars: c, $h-k=100 \mu m$, d, f, $g=20 \mu \mathrm{m}$, e, $l-p=10 \mu \mathrm{m}$.

GenBank Numbers - SSU: MW048786, LSU: MW041254, ITS: MW041570

Notes - Our species illustrated here has $310 \times 50 \mu \mathrm{m}$ sized, broadly cylindric-clavate and slightly curved asci containing broad, asymmetric, muriform, $55 \times 20 \mu \mathrm{m}$ sized ascospores. These morphological characters resemble $P$. trichostoma as described by Fuckel (1870). Phylogenetically, our isolate KUMCC 16-0123 clusters with three strains CBS. 328.53, CBS 391.54 and CBS 392.54 identified as P. trichostoma (Marin-Felix et al. 2019) and another isolate KUMCC 16-0120, a host record on Bothriochloa ischaemum and first record from Russia (Hyde et al. 2020). There were no 
base pair differences present in the LSU or ITS gene regions in all these strains. Therefore, we identify our species is $P$. trichostoma.

\section{Conclusions}

Pyrenophora trichostoma is a known severe pathogen on cereal crops, especially wheat. There are numerous records of the species as a pathogen, but there is a lack of molecular data related to these reports, in GenBank. A proper taxonomic revision based on morphological identification and classification is needed. Therefore, further recollections and establishing a suitable type herbarium for future studies is necessary. The addition of more molecular data will help to confirm its phylogenetic placement and aid in developing modern DNA techniques for plant disease identification.

\section{Acknowledgements}

The authors acknowledge the Mushroom Research Foundation, Chiang Rai for funding this research.

\section{References}

Ariyawansa HA, Kang JC, Alias SA, Chukeatirote E et al. 2014 - Pyrenophora. Mycosphere 5, 351-362.

Cash EK. 1953 - A checklist of Alaskan fungi. Plant Disease Reporter (Supplement) 219, 1-70.

Checa J. 2004 - Dictyosporic Dothideales. Fl Mycol Iberica 6, 1-162.

Chlebicki A. 1993 - Preliminary studies on microfungi from decaying stems of Calamagrostis arundinacea in natural habitats I. List of species. Polish Botanical Studies 5, 89-95.

Chomnunti P, Hongsanan S, Hudson BA, Tian Q et al. 2014 - The Sooty Moulds. Fungal Diversity 66, 1-36.

Conners IL. 1967 - An Annotated Index of Plant Diseases in Canada and Fungi Recorded on Plants in Alaska, Canada and Greenland. Research Branch, Canada Department of Agriculture 1251, $1-381$.

Cooke WB. 1955 - Fungi of Mount Shasta. Sydowia 9, 94-215.

Ciuffetti LM, Tuori RP. 1999 - Advances in the characterization of the Pyrenophora triticirepentis-wheat interaction. Phytopathology 89, 444-449.

Dennis RWG. 1978 - British Ascomycetes. J. Cramer, Vaduz.

Farr DF, Rossman AY. 2020 - Fungal Databases, U.S. National Fungus Collections, ARS, USDA. https://nt.ars-grin.gov/fungaldatabases/ (Accessed $5^{\text {th }}$ September 2020).

Farr ML, Stevenson JA. 1963 - Eine erganzungsliste bolivianischer pilze. Sydowia 17, 37-69.

Felsenstein J. 1985 - Confidence limits on phylogenies: an approach using the bootstrap. Evolution 39, 783-791.

Fries E. 1823 - Systema mycologicum: Vol. II.

Fries W. 1870 - De anacoluthis Sophocleis: pars prior (Doctoral dissertation).

Fuckel L. 1870 - Symbolae mycologicae. Beiträge zur Kenntniss der Rheinischen Pilze. Jahrbücher des Nassauischen Vereins für Naturkunde 23-24, 1-459.

Goonasekara ID, Camporesi E, Bulgakov TS, Phookamsak R et al. 2019 - Two novel species of Parastagonospora (Phaeosphaeriaceae, Pleosporales) on grasses from Italy and Russia. Asian Journal of Mycology 2, 170-182.

Greuter W, Poelt J, Raimondo FM. 1991 - A checklist of Sicillian fungi. Bocconea 2, 222.

Gupta S, Loughman R. 2001 - Current virulence of Pyrenophora teres on barley in Western Australia. Plant Disease 85, 960-966.

Hall TA. 1999 - BioEdit: a user-friendly biological sequence alignment editor and analysis program for Windows 95/98/NT. Nucleic Acids Symposium Series 41, 95-98.

Hanlin RT. 1963 - A revision of the Ascomycetes of Georgia. Georgia Agricultural Experimental Station, Mimeo Ser n.s. 175, 1-65. 
Hosford RM. 1971 - Form of Pyrenophora trichostoma Pathogenic to Wheat and Other Grasses. Phytopathology 61, 28-32.

Hosford RM. 1982 - Tan spot. Tan spot of wheat and related diseases. North Dakota State University, Fargo, 1-24.

Huelsenbeck JP, Ronquist F. 2001 - MRBAYES: Bayesian inference of phylogenetic trees. Bioinformatics 17, 754-755.

Hyde KD, de Silva NI, Jeewon R, Bhat DJ et al. 2020 - AJOM new records and collections of fungi: 1-100. Asian Journal of Mycology 3, 22-294.

Index Fungorum. 2020 - http://www.indexfungorum.org/Names/Names.asp (accessed 9 September 2020).

Index of Plant Diseases in the US. 1960 - U.S.D.A. Agricultural Handbook 165, 1-531.

Jayasiri SC, Hyde KD, Ariyawansa HA, Bhat J et al. 2015 - The Faces of Fungi database: fungal names linked with morphology, phylogeny and human impacts. Fungal Diversity 74, 3-18.

Kingsland GC. 1991 - Spot lesion of barley net blotch disease caused by Drechslera teres f. sp. maculata observed in South Carolina. Plant Disease 75, 537.

Kishino H, Hasegawa M. 1989 - Evaluation of the maximum likelihood estimate of the evolutionary tree topologies from DNA sequence data, and the branching order in Hominoidea. Journal of molecular evolution 29, 170-179.

Kodsueb R, Dhanasekaran V, Aptroot A, Lumyong S et al. 2006 - The family Pleosporaceae: intergeneric relationships and phylogenetic perspectives based on sequence analyses of partial 28S rDNA. Mycologia 98, 571-83.

Krupinsky JM. 1982 - Observations on the host range of isolates of Pyrenophora trichostoma. Canadian Journal of Plant Pathology 4, 42-46.

Krupinsky JM, Berdahl JD. 1984 - Septoria spraguei, Pyrenophora trichostoma, and Cochliobolus sativus incidence on Russian wildrye grass leaves and $S$. spraguei host range. Plant Disease 68, 13-16.

Lamari L, Bernier CC. 1989 - Virulence of isolates of Pyrenophora tritici-repentis on 11 wheat cultivars and cytology of the differential host reactions. Canadian Journal of Plant Pathology 11, 284-90.

Marin-Felix Y, Hernández-Restrepo M, Iturrieta-González I, García D et al. 2019 - Genera of phytopathogenic fungi: GOPHY 3. Studies in mycology 94, 1.

Mendes MAS, da Silva VL, Dianese JC. 1998 - Fungos em Plants no Brasil. EmbrapaSPI/Embrapa-Cenargen, Brasilia.

Miller MA, Pfeiffer W, Schwartz T. 2010 - Creating the CIPRES Science Gateway for inference of large phylogenetic trees. In: Proceedings of the gateway computing environments workshop (GCE) 14 Nov 2010. Institute of Electrical and Electronics Engineers, New Orleans, LA, 1-8.

Moreno MV, Stenglein SA, Perelló AE. 2012 - Pyrenophora tritici-repentis, causal agent of tan spot: a review of intraspecific genetic diversity. Molecular basis of plant genetic diversity 30, 297-330.

Nylander JAA. 2004 - MrModeltest 2.0. Program distributed by the author. Evolutionary Biology Centre, Uppsala University.

Porta-Puglia A, Delogu G, Vannacci G. 1986 - Pyrenophora graminea on winter barley seed: effect on disease incidence and yield losses. Journal of Phytopathology 117, 26-33.

Rambaut A. 2012 - FigTree: Tree figure drawing tool, version 1.4.0. Institute of Evolutionary Biology, University of Edinburgh.

Rannala B, Yang Z. 1996 - Probability distribution of molecular evolutionary trees: a new method of phylogenetic inference. Journal of Molecular Evolution 43, 304-311.

Rebentisch JF. 1804 - Prodromus Flora Neomarchicae, Schüppel, Berlin.

Scheuer C. 1988 - Ascomyceten auf Cyperaceen und Juncaceen im Ostalpenraum. Bibliotheca Mycolologica 123, 1-274.

Shoemaker RA. 1959 - Nomenclature of Drechslera and Bipolaris, grass parasites segregated from 'Helminthosporium'. Canadian Journal of Botany 37, 879-887.

Shoemaker RA. 1962 - Drechslera Ito. Canadian Journal of Botany 40, 809-836. 
Sivanesan A. 1984 - The bitunicate ascomycetes and their anamorphs, J. Cramer, Vaduz.

Sivanesan A. 1987 - Graminicolous species of Bipolaris, Curvularia, Drechslera, Exserohilum and their teleomorphs. CAB International.

Stamatakis A, Hoover P, Rougemont J. 2008 - A rapid bootstrap algorithm for the RAxML web servers. Systematic Biolology 57, 758-771.

Stamatakis A. 2014 - RAxML version 8: a tool for phylogenetic analysis and post-analysis of large phylogenies. Bioinformatics 30, 1312-1313.

Swofford DL. 2002 - PAUP: phylogenetic analysis using parsimony, version 4.0 b10. Sinauer Associates, Sunderland.

Tai FL. 1979 - Sylloge Fungorum Sinicorum. Science Press, Acad Sin, Peking.

Tekauz A. 1983 - Reaction of Canadian barley cultivars to Pyrenophora graminea, in the incitant of leaf stripe. Canadian Journal of Physiology and Pharmacology 5, 294-301.

Unamuno PLM. 1941 - Enumeracion y distribucion geografica de los ascomicetos de la Peninsula Iberica y de las Islas Baleares. Memorias Real Academia de Ciencias Exactas, Madrid 8, 1403.

Vilgalys R, Hester M. 1990 - Rapid genetic identification and mapping of enzymatically amplified ribosomal DNA from several Cryptococcus species. Journal of Bacteriology 172, 4238-4246.

Wehmeyer LE. 1961 - A world monograph of the genus Pleospora and its segregates. University of Michigan Press, Ann Arbor.

White TJ, Bruns T, Lee S, Taylor J. 1990 - Amplification and direct sequencing of fungal ribosomal RNA genes for phylogenetics. In: Innis MA, Gelfand DH, Sninsky JJ, White TJ. (Eds) PCR protocols: a guide to methods and applications. Academic, San Diego, 315-322.

Wiese MV. 1987 - Compendium of Wheat Diseases. American Phytopathological Society.

Zhang G, Berbee ML. 2001 - Pyrenophora phylogenetics inferred from ITS and glyceradehyde-3phosphate dehydrogenase gene sequences. Mycologia 93, 1048-1063.

Zhaxybayeva O, Gogarten JP. 2002 - Bootstrap, Bayesian probability and maximum likelihood mapping: exploring new tools for comparative genome analyses. BMC Genomics 3, 4. 